Purdue University Purdue e-Pubs

$4-27-2010$

\title{
Comparison of Fixed Versus Variable Biofuels Incentives
}

Wallace E. Tyner

Purdue University,wtyner@purdue.edu

Farzad Taheripour

Purdue University

David Perkis

Purdue University

Follow this and additional works at: http://docs.lib.purdue.edu/gpridocs

Cart of the Energy Policy Commons

Tyner, Wallace E.; Taheripour, Farzad; and Perkis, David, "Comparison of Fixed Versus Variable Biofuels Incentives" (2010). PPRI Digital Library. Paper 5.

http://docs.lib.purdue.edu/gpridocs/5

This document has been made available through Purdue e-Pubs, a service of the Purdue University Libraries. Please contact epubs@purdue.edu for additional information. 


\title{
COMPARISON OF FIXED VERSUS VARIABLE BIOFUELS INCENTIVES
}

\author{
Wallace E. Tyner \\ James and Lois Ackerman Professor \\ Department of Agricultural Economics \\ Purdue University \\ West Lafayette, IN 47907 \\ wtyner@purdue.edu \\ phone 1-765-494-0199 \\ fax 1-765-494-9176 \\ Farzad Taheripour \\ Energy Economist \\ Department of Agricultural Economics \\ Purdue University \\ West Lafayette, IN 47907 \\ David Perkis \\ Graduate Assistant \\ Department of Agricultural Economics \\ Purdue University \\ West Lafayette, IN 47907
}




\section{Abstract}

We evaluated several variants of a variable biofuel subsidy and compared them with the fixed subsidy and Renewable Fuel Standard. We used two different modeling approaches. First we used a partial equilibrium model encompassing crude oil, gasoline, ethanol, corn, and ethanol by-products. Second, we used a stochastic simulation model of a prototypical ethanol plant. From the partial equilibrium analysis, it appears the variable subsidy provides a safety net for ethanol producers when oil prices are low; yet, it does not put undue pressure on corn prices when oil prices are high. At high oil prices, with a variable subsidy, the level of ethanol production is driven entirely by market forces. From the plant level stochastic analysis, essentially the same conclusions are reached. The variable subsidy can provide essentially the same expected NPV as the fixed subsidy but with a lower risk for the producer, a lower probability of a loss from the investment, and often at a lower expected cost to government. Finally, in the U.S., the ethanol industry is up against a blending limit called the blend wall. If the blending wall remains in place, it does not matter much what other policy options are used.

Key words: ethanol policy, biofuel incentives 


\section{Introduction}

The United States has used and continues to use a variety of incentives to promote development and operation of the ethanol industry. Since the Energy Policy Act of 1978, ethanol has received a tax credit of one sort or another (Tyner, 2008a). Today the main incentives are the volumetric ethanol excise tax credit (VEETC) of 11.9 cents per liter of ethanol blended, the Renewable Fuel Standard (RFS) (U.S. Congress, 2007), and a small producer tax incentive. There is also a tariff on imported ethanol of 14.3 cents per liter plus $2.5 \%$ of the value of the import. At today's prices, the total import tariff is about 15.6 cents per liter (Taheripour and Tyner, 2008). The imported ethanol is eligible for the 11.9 cent blender credit, so the net tariff is 3.7 cents per liter. All of these direct financial incentives are fixed amounts per liter of ethanol or other biofuel produced and blended with gasoline. This paper focuses on the subsidy and RFS.

The RFS is a mandate requiring blending of an amount specified each year of each type of biofuel. The timing and quantities of the RFS are illustrated in Figure 1. Corn ethanol is in the category called conventional biofuels and reaches a plateau of 56.8 billion liters per year in 2015 . Current national capacity including shut down plants is about 47.3 billion liters with another 7.6 billion under construction (Renewable Fuel Association), so we are near the 56.8 billion liter plateau for the RFS. Economically, the RFS functions somewhat like a hidden variable incentive because it requires gasoline type fuel vendors to use a specified amount of biofuel regardless of its price or the price of crude oil and 
gasoline. So at $\$ 40$ per barrel of crude oil, the implicit incentive is much greater than at $\$ 100$ crude oil, and the incentive goes away at higher oil prices as the market actually produces more than the mandated amount, if there are no other constraints such as a blending wall. We will discuss this issue later when we evaluate the RFS compared with other policy options. The basic objective of this paper is to provide an economic analysis of the fixed subsidy, variable subsidy, and Renewable Fuel Standard.

\section{Basic economics of the current market and policy options}

Figure 2 displays the basic economics of the fixed subsidy and a nonbinding RFS. A non-binding RFS is one that is below the level that is being produced by the market. That has been the case historically. The market has always produced a quantity greater than the RFS, so the RFS has no real effect on market price or quantity. The fixed subsidy just shifts up the market demand curve by the amount of the subsidy (note that the demand for ethanol represents the blender derived demand). In other words, because the blender receives the VEETC credit, s/he is willing to pay up to 11.9 cents more per liter than would be the case without the subsidy. In this case, the RFS is drawn to the left of the intersection of the supply curve and the market demand curve. Thus, the RFS has no impact on either market price or quantity. Market price $\left(\mathrm{P}^{\star}\right)$ and quantity $\left(Q^{*}\right)$ are determined by the intersection of the supply curve and the demand plus subsidy curve. If there were no subsidy, the market price and quantity would be $\mathrm{P}^{\mathrm{m}}$ and $\mathrm{Q}^{\mathrm{m}}$. The ethanol producer gets the difference between $\mathrm{P}^{*}$ and $\mathrm{P}^{\mathrm{m}}$ of the subsidy with the rest going to the blender. The sharing of the subsidy between 
the ethanol producer and the blender depends on the supply and demand elasticities (Taheripour and Tyner, 2007).

Figure 3 shows the case of a binding RFS. For this case, the RFS is to the right of the intersection of the supply curve and the demand plus subsidy curve. The mandated quantity of ethanol is the level of the RFS, and the price is $\mathrm{P}^{\mathrm{RFS}}$. Thus, for quantities of ethanol less than the RFS, the demand curve is vertical at the RFS quantity (totally inelastic). The price $\left(P^{R F S}\right)$ is given by the intersection of the RFS line and the supply curve. The market price for ethanol and the market quantity are higher than they would be in the absence of the binding RFS. In this case, the ethanol producer should receive $\mathrm{P}^{\mathrm{RFS}}$ for each unit of ethanol produced at the mandated level of RFS. However, the economic value of ethanol at the RFS is just $P_{b}$, the intersection of the demand with no subsidy and the RFS line. The difference between $\mathrm{P}^{\mathrm{RFS}}$ and $\mathrm{P}^{\mathrm{B}}$ can be considered as a rent (or reduction in losses) for ethanol producers. When there is a government subsidy, the subsidy has no impact on the quantity or price of ethanol - it just changes the allocation of the rent.

In the case of the non-binding RFS, the subsidy induced higher ethanol production. With the binding RFS, the subsidy has no impact on ethanol production or price. As noted before, the ethanol demand curve is derived from the gasoline demand and is defined uniquely for each oil price. Each increase in the oil price would induce an outward shift in the demand for ethanol, which eventually (as shown in Figure 2) would render the RFS non-binding again, and ethanol production would be driven by market supply and demand forces. 


\section{Blend wall}

Figure 4 illustrates the economics of a binding blend wall. We developed this framework to represent the current U.S. ethanol market condition. A blend wall is a physical or technical constraint on the amount of ethanol that can be blended. In the U.S. currently, it is dictated by the 10 percent blending limit. However, we cannot blend 100 percent of gasoline, so the effective blend wall is around 9 percent or less, or somewhere between 42 and 45 billion liters of ethanol (Tyner and Taheripour, 2008b). Moving down the demand plus subsidy curve from left to right, the market demand is the demand up to the blend wall. At that point, no more ethanol can be absorbed because of the physical blending limit. So at the blend wall, the demand plus subsidy curve becomes vertical, and the market price is the intersection of the blend wall and the supply curve. The market price in Figure $4\left(\mathrm{P}^{\mathrm{BW}}\right)$ is lower than $\mathrm{P}^{*}$ and $\mathrm{P}^{\mathrm{m}}$. In this case the subsidy is shared between the consumer and blender with none going to the ethanol producer. The subsidy has no impact on market quantity because that is set by the physical limit of the blend wall. But in this case, the blend wall forces the price down to the supply curve at the blend wall quantity. Essentially, that explains why we observe shut down capacity in the current condition. We are at or near the effective blend wall, and more ethanol is being offered to the market than can be absorbed, so the price falls. Essentially, in the presence of blending wall ethanol moves from being priced primarily by the crude and gasoline prices to being priced primarily by the corn price. In this case, the price of corn will be the major determinant of ethanol price. In the presence of blending wall capacity 
comes in or out based on changes in the price of corn relative to ethanol. Currently, the blend wall is the biggest issue facing the ethanol industry.

The policy analysis that follows assumes the blending wall problem is solved. It is important to understand that if the blending wall remains effective, then none of the other policy options effectively matter. The RFS cannot be enforced because the EPA cannot require blenders to blend that which they cannot legally blend. The subsidy, whether fixed or variable, does not matter because it all goes to the consumer and the blender and not to the ethanol producer.

\section{Policy Analysis}

In our prior work, we have evaluated variable incentives compared with the fixed VEETC and RFS (Quear and Tyner, 2006; Tyner and Taheripour, 2008a; Tyner, 2007a; Tyner, 2007b; Tyner, 2008b; Tyner and Quear, 2006; Tyner and Taheripour, 2008d). However, we have not performed a detailed evaluation of different variants of the variable incentive. In this paper we define several variants of a variable biofuel subsidy and compared them with the fixed subsidy and RFF using a partial equilibrium model which links the US energy and agricultural market (Taheripour and Tyner 2008). In addition, we develop a stochastic cost-benefit analysis framework to compare impacts of the variable and fixed subsidies on the profitability of a representative ethanol producer under uncertain conditions. The stochastic model simulates uncertainty in crude oil, gasoline, and corn prices, and calculates the plant investment net present value distribution under a fixed and variable type incentive. The stochastic model is 
designed to reflect the inherent market uncertainty from the perspective of a representative ethanol plant.

Since the existing fixed subsidy expires in 2010 , Congress will be compelled to act on it in one way or another in 2010. Hence it is important to provide additional information on possible options in choosing future directions. The rest of the paper is divided into the following sections:

1) An analysis of different variable and fixed subsidy options and the RFS.

2) An analysis of the same fixed and variable subsidy options using a stochastic ethanol plant financial analysis model.

3) Summary and conclusions of the research.

\section{Evaluation of policy options}

To perform our policy analyses we first update our partial equilibrium model to expand the set of options evaluated. Appendix A contains a summary of the model and an explanation of how it works. The two main changes made in the model for this analysis are as follows:

1) In previous work we have included a $5 \%$ gasoline demand shock to account for growth in income and population over time. This shock is independent of the standard linkage between the price of gasoline and quantity demanded. For this paper, we have eliminated the demand shock for two main reasons: (1) Because of the recession, incomes have fallen, and demand has fallen due to that income effect; and (2)The Energy Independence and Security Act of 2007 (EISA) (U.S. Congress, 2007) contains a requirement for a substantial increase in automobile fuel 
economy by 2020. Thus, for any given population and income, gasoline demand will be lower because of the increase in the Corporate Average Fuel Economy (CAFE) standard.

2) We changed the linkage between the cost of producing corn and the price of crude oil. There is, of course, still a link between the crude oil price and the corn cost of production. However, in 2009, the link between the price of crude oil and the price of natural gas has been disrupted. There have been substantial new discoveries of natural gas in the U.S., which have caused the price of natural gas to plummet. The price of natural gas today is no more than $1 / 3$ what it was a year ago. Natural gas is the main ingredient in producing nitrogen fertilizer - a main cost component for corn production. So while we retained the link between the corn production cost and the price of crude oil, we cut the oil price coefficient in half for this analysis.

The variable subsidy, as we have defined it in the past, has two components: the trigger price of oil below which the subsidy takes effect and the rate of increase in the subsidy as the oil price drops below the trigger price. For example, if the subsidy is triggered when the crude oil price drops below $\$ 80$ and increases at a rate of 0.50 cents per liter per dollar of change in the crude price, the applied subsidy at various oil prices would be as shown in Table 1. The variable subsidy could be operated on either a monthly or quarterly basis. For example, if a quarterly basis were used and the crude oil price were $\$ 60$ in quarter one, then the subsidy on ethanol produced in quarter two would be 
$\$ 0.15 /$. of ethanol according to Table 1 . The same approach would apply if assuming a monthly basis.

In the analysis that follows, we display results for the following options:

- Fixed subsidy of 11.9 cents/liter

- Fixed subsidy of 6.6 cents/liter

- Variable subsidy starting at $\$ 70, \$ 80$, and $\$ 90$ of crude oil price per barrel

- Variable subsidy with a rate of increase of $0.40,0.46$, and 0.53 cents/liter per dollar drop in the crude oil price (run at each oil price starting point)

- RFS of 56.8 billion liters

- No subsidy or RFS

In these cases we assume that there is no blending wall. In this analysis ethanol producers will receive a share of the subsidy, whether fixed or variable, depending on the market conditions and elasticities of the demands for and supplies of gasoline, ethanol, and corn. Furthermore, we assume that the RFS is fully enforced.

Results from this model are numerous. First, Figure 5 compares ethanol production under alternative policies. In particular, this figure compares four policies: the fixed 11.9 cent subsidy, a variable subsidy starting at $\$ 90$ crude oil with a 0.46 cents/liter rate of increase, no subsidy, and the RFS. Several important points emerge from this first set of results:

- Crude oil price must be at least $\$ 60$ for there to be any ethanol production if there is no subsidy or RFS. 
- At low oil prices, the variable subsidy option results in greater ethanol production than the fixed option.

- At oil prices below $\$ 80$, the RFS results in greater ethanol production than either the fixed or variable subsidy.

- At oil prices greater than $\$ 80$, the fixed subsidy yields greater ethanol production than any of the other options. As we will see below, it also induces higher corn prices than the other options.

- At oil prices above $\$ 80$, the variable subsidy and no subsidy options produce the same results because the variable subsidy ends at $\$ 90$.

- At oil prices of $\$ 120$ and higher, the no subsidy, variable subsidy, and RFS options all yield the same results. There is no subsidy at these oil prices for the variable subsidy, and the RFS is no longer binding, meaning the market is producing more than the mandated 56.8 billion liters.

Figure 6 contains the corn price results for the same policy alternatives mentioned above. The main conclusions with respect to corn prices are as follows:

- Corn price is higher under the variable subsidy than the fixed subsidy for crude prices of $\$ 60$ and below.

- Corn price goes to $\$ 255 / \mathrm{mt}$ at $\$ 160$ crude oil under the fixed subsidy, about $\$ 34 / \mathrm{mt}$ higher than the other options.

Figure 7 contains the results of the same simulations for corn exports. The main conclusions regarding corn exports are as follows: 
- Corn exports are higher at low oil prices for the fixed and no subsidy cases compared to the variable subsidy and RFS cases. That stands to reason because the variable subsidy and RFS are a more potent incentive for ethanol production at low oil prices than either the no subsidy or fixed subsidy cases. In particular, there is no ethanol production at low oil prices without the subsidy, so more corn gets allocated to exports.

- At high oil prices, the RFS and variable subsidy lead to a lower drop in exports than the fixed subsidy case. At high oil prices, the RFS is no longer binding, and the variable subsidy is the same as no subsidy since the variable subsidy ends at $\$ 90$ crude oil in this case.

- At $\$ 80$ crude oil, the variable subsidy yields higher exports than either the RFS or fixed subsidy, which are about the same.

Next, we compare the $\$ 90$ variable subsidy with three different slopes against the fixed subsidy at 6.6 cents. The other cases are dropped from this graph for clarity of presentation. Figure 8 contains the results for ethanol production, and Figure 9 for corn price. Table 2 contains the complete ethanol and corn price results for all three starting points and rates of change. For ethanol production and corn price, the variable subsidy yields higher levels at oil prices of $\$ 40$ and $\$ 60$, and the 6.6 cent fixed subsidy is about the same as the variable subsidy at $\$ 80$ crude oil. For crude oil of $\$ 100$ or higher, the fixed subsidy yields both higher ethanol production and corn price. For the variable subsidy beginning at $\$ 90$, the higher slope of 0.53 cents/liter per dollar actually 
results in higher ethanol production at $\$ 40$ crude oil than at $\$ 100$ crude because the subsidy grows to be quite large at low oil prices.

The 0.40 and 0.46 cents/liter per dollar rates of change produce more reasonable results with the $\$ 90$ starting point in that the safety net is provided, but not so much as to change significantly the profitability as oil price increases. On the other hand, with the $\$ 70$ starting point, the higher slope is needed to stimulate significant ethanol production at low oil prices. The $\$ 80$ case, as would be expected, is in between these two.

Based on these results, it appears that the variable subsidy can provide a safety net for periods of low oil prices, while not providing a stimulative effect when oil prices are higher. We now turn to the analysis of these options performed using an ethanol plant level model.

Ethanol plant simulation model based analysis

The ethanol plant based simulation analysis is performed using a modified plant level model (Dale and Tyner, 2006a, b; Perkis et al., 2008). The model was previously used to evaluate new technology options in corn ethanol production. It was modified for purposes of this analysis to permit stochastic analysis of the ethanol plant profitability. While a number of changes were made, we will summarize briefly here the main changes that are important to this paper:

- Crude oil price is uncertain. The price in year one of production is taken from a triangular distribution. The base case is the DOE IEA 2009 Energy Outlook base range for year 2011 , with a minimum of $\$ 53$, most likely value of $\$ 62$, and maximum of $\$ 102$. We also ran a second case with a 
maximum value of $\$ 65$, which yields an average starting price of $\$ 61$ (about the market value when this analysis was performed). Then we simulated an annual percentage price change based on the variability of crude oil prices between 1981 and 2008. All the market prices over that period were converted to real values using the Consumer Price Index (CPI). The annualized inflation rate over this period was 3.2 percent. Using the Best Fit feature of the @Risk software add-in for Microsoft Excel, we found that a normal distribution fit the annual price changes quite well. For this analysis we assume an average annual percent price change of zero and use the standard deviation from that distribution.

- We estimated the historical relationship between crude oil and gasoline using monthly data for April 2006 - March 2009. We found that using the natural log form for both crude and gasoline prices worked well and explained $88 \%$ of the variability of the gasoline price by the crude oil price. The residual in this estimation makes the gasoline price only a bit less dependent on the crude oil price.

- We also estimated the link between crude oil and corn over this same period, again assuming the natural log form for prices, but this relationship was not as strong explaining 25 percent of the variability. In this case the regression residual introduced considerable corn price variability.

- We used the historical empirically estimated price link between corn and DDGS. 
- For this paper, we assumed volumetric pricing of ethanol. That is, we assumed the ethanol price equaled the gasoline price plus any subsidy in effect.

- Even though the model allows the subsidy pass-through percentage to producers to be stochastic, we used $100 \%$ pass through in this analysis to have a good basis for comparison of alternatives.

The policy options examined in this part of the research were essentially the same as in the previous section, but we focused more on the rate of change of 0.46 cents/liter per dollar of crude oil price difference, as this rate appeared to work well in the previous section's results. One additional approach we added in this section is letting the starting point for the variable subsidy be held constant in nominal terms or be adjusted each year by the rate of inflation. For example, in the nominal case, assuming a $\$ 90$ starting point for the variable subsidy, the nominal level did not change over the assumed 25 year plant life (two years of construction and 23 of operation). The real case increased the crude trigger price each year by the rate of inflation.

The simulations were performed with @Risk software (@Risk, 2008). @Risk is an add-in for the Excel spreadsheet that permits Monte Carlo simulation. That is, it calculates the inherent uncertainty in all the output values given the uncertainty reflected (and described above) in input variables. The spreadsheet is recalculated many times (we used 10,000 iterations for each simulation). @Risk calculates the mean, standard deviation, and other parameters of the output distributions. 
The results for the nominal subsidy starting point are provided in Table 3. The first column contains the parameters of the system being simulated, with the variable subsidy systems denoting in parentheses both the trigger price and the rate of change ( $\$ /$ barrel crude, $\$ /$ iter ethanol per $\$ /$ barrel crude). The column labeled "value" contains the non-stochastic results for the Net Present Value (NPV) after 25 years of construction and operation. The columns labeled mean and SD are the average NPV and the standard deviation of NPV for each policy option. The column labeled SD/mean is the coefficient of variation (CV), which is a standard measure of riskiness of the investment. The column labeled " $\%<0$ " is the probability that the investment will result in a loss. The two columns under subsidy NPV are the average and standard deviation of government subsidy costs. Finally, the two columns under Govt NPV Revenue are the NPV average and standard deviation of the government's net subsidy cost after allowing for government revenue from taxes paid over the plant lifetime. The difference between the subsidy NPV and Govt. Rev. NPV is the NPV of taxes paid. For example, for the fixed subsidy case, the NPV subsidy cost is $\$ 316$ million, but the net cost is $\$ 145$ million, so $\$ 171$ million is the NPV of taxes paid over the 25 years.

For the higher priced case from DOE (the average starting oil price is \$73.55), it is instructive to compare the fixed subsidy (11.9 cent) case with the $\$ 100$ starting point variable subsidy. Note that the fixed subsidy mean or expected NPVs are similar to the values with no risk analysis, but the variable subsidy cases are substantially higher. That is because it is only with the 
stochastic analysis that one can get a true indication of the functioning of the variable subsidy. Without the price varying each year, only the "expected" subsidy gets calculated. Technically, the large difference occurs because the variable subsidy is a type of non-linear transformation that makes the deterministic spreadsheet case give very different results from the Monte Carlo simulations. The expected plant NPVs are $\$ 343$ million and $\$ 326$ million for the fixed and variable cases, respectively. In other words the expected NPVs are about the same. The coefficients of variation $(\mathrm{CVs})$ are 0.95 and 0.73 for the fixed and variable cases respectively. A higher CV means higher risk, so the variable subsidy case is less risky for the firm. The probability of a loss is $6.6 \%$ for the fixed subsidy case and $0 \%$ for the variable subsidy case, another indicator of risk. Finally, the expected NPV subsidy cost is $\$ 316$ million for the fixed case and $\$ 289$ for the variable case. Thus the variable subsidy case costs the government less yet provides about the same expected NPV to the firm but at lower risk. For the second case, with the projected crude oil starting price beginning at $\$ 61$ in year 2011 , the $\$ 90$ trigger point for the variable subsidy has similar results. For example, the fixed subsidy has a $12.3 \%$ probability of loss, while the variable subsidy loss probability is essentially zero. In fact, all shaded rows represent policy options which both decrease the probability of a loss to the firm and lower the expected expense to taxpayers when compared to the fixed subsidy outcomes.

Table 4 provides the same results for the inflation adjusted trigger price for the variable subsidy. In this case for the higher projected crude starting price of 
$\$ 73.55$, the inflation adjusted crude trigger prices of $\$ 70$ to $\$ 80$ yield results comparable to the fixed subsidy case except, as before, the variable subsidy involves less risk as measured by CV and probability of a loss. For the projected crude starting price of $\$ 61$, the $\$ 70$ trigger price has a slightly higher NPV than the fixed subsidy case, but significantly lower risk. For that case, the expected government subsidy cost is slightly higher as well. It is logical that the subsidy's crude trigger price for the inflation adjusted case would be lower than the fixed trigger price case. In a sense, it is more flexible in that it adjusts higher with increases in inflation. Figure 10 illustrates the win-win zone for both the real and nominal trigger prices. The win-win zone is defined as the region in which firm risk goes down and government cost goes down.

\section{Other issues}

In addition to the comparison of risk sharing and cost presented above, there are some other issues that merit consideration in the policy decision. The two main categories are implementation issues and interaction of the subsidy policy with the RIN market.

Implementation issues

As described briefly above, the variable subsidy would be implemented either on a quarterly or monthly basis. It would make use of a publically available and reported crude oil price so that everyone in the market would be able to calculate or estimate the subsidy level for the following period. There would be a lag of one period, so the Q2 subsidy would be calculated from Q1 oil prices. Once fixed for the quarter, the subsidy would be implemented just as under the 
current system. That is, blenders would take a deduction from their excise tax bill for the ethanol blended during the quarter using the subsidy value for that quarter. So in that sense, there would be no difference in implementation between the current fixed VEETC and variable VEETC except that the level would change each period.

In periods of high volatility, it is possible that just before and after the subsidy level changed, firms would attempt to move up or back transactions to take advantage of higher subsidies in one period or the other. It is not expected that this time arbitrage would pose significant problems, but it might merit further review.

\section{Relationship between the subsidy and RIN market}

RINs (Renewable Fuel Identification Numbers) are the mechanism for enforcing the RFS. At the end of each year, each fuel vendor must have enough RINs to satisfy its blending quota under the RFS. When the RFS is not binding, RINs have little or no value because firms can easily meet the RFS blending quota. When the RFS is binding, the RIN value is driven by the difference between the market price with the binding RFS ( $P^{R F S}$ in Figure 3) and the price that holds in the absence of the RFS (either $\mathrm{P}^{*}$ or $\mathrm{P}^{\mathrm{m}}$ in Figure 3 depending on whether or not there is a subsidy). The subsidy is the vertical distance between the market demand and demand plus subsidy curves. With a variable subsidy, the distance between the market demand curve and the market plus subsidy curve would vary each period (quarter or month). Since the subsidy effectively reduces the value of the RIN, it is possible a variable subsidy would introduce 
more volatility in the RIN market at low crude oil prices. The RIN quota must be satisfied annually, and the variable subsidy could change quarterly, so that might introduce another complicating element into the RIN market when crude oil price is low.

It is impossible to quantify the magnitude of these effects. The RIN market in recent months has been very stable with little trading activity. There is no doubt that a variable subsidy adds another factor for blenders to consider, but one would expect that with some experience, market actors would become accustomed to the changes and adjust accordingly. However, we have no way of estimating what additional cost market participants might incur, if any.

\section{Summary and conclusions}

If the blending wall remains in place, it does not matter much what other policy options are used. The RFS would have to be waived down to the blend wall level. In the presence of the blending wall the subsidy (VEETC), whether fixed or variable, goes to the consumers, blenders, and refiners and not to the ethanol producer. The policy analysis we did assumes the blend wall problem is solved.

We have evaluated several variants of a variable subsidy and compared them with the fixed subsidy and RFS. In general, it appears the variable subsidy provides a safety net for ethanol producers and corn growers when oil prices are low; yet, it does not put undue pressure on corn prices when oil prices are high. At high oil prices, with a variable subsidy, the level of ethanol production is driven entirely by market forces and not by government interventions. 
From the plant level stochastic analysis, essentially the same conclusions are reached. The additional information is that the variable subsidy can provide essentially the same expected NPV as the fixed subsidy but with a lower risk for the producer, a lower probability of a loss from the investment, and often at a lower expected cost to government. 


\section{Appendix A}

\section{Brief Model Description}

The model contains integrated markets of corn and gasoline (Tyner and Taheripour, 2008c; Tyner and Taheripour, 2008d). The supply side of the corn market consists of identical corn producers. They produce corn using constant returns to scale Cobb-Douglas production functions and sell their product in a competitive market. Under these assumptions, we can define an aggregated Cobb-Douglas production function for the whole market. In the short-run, the variable input of corn producers is a composite input, which covers all inputs such as seed, fertilizers, chemicals, fuel, electricity, and so on. In the short run, capital and land are fixed. The demand side of the corn market consists of three users: domestic users which use corn for feed, food, and industrial purposes; foreign users, and ethanol producers. We model the domestic and foreign demands with constant price elasticity functions. The foreign demand for corn is more elastic than the domestic demand. The demand of the ethanol industry for corn is a function of the demand for ethanol.

The gasoline market has two groups of producers: gasoline and ethanol producers. It is assumed that ethanol is a substitute for gasoline with no additive value. The gasoline and ethanol producers produce according to short run CobbDouglas production functions. The variable input of gasoline producers is crude oil and the variable input of ethanol producers is corn. Both groups of producers are price takers in product and input markets. We model the demand side with a 
constant price elasticity of demand. The constant parameter of this function can change due to changes in income and population. We assume that the gasoline industry is well established and operates at long run equilibrium, but the ethanol industry is expanding. The new ethanol producers opt in when there are profits. There is assumed to be no physical or technical limit on ethanol production only economic limits (Tyner et al., 2008).

The model is calibrated to 2006 data and then solved using Mathematica (Wolfram 1999) for several scenarios. Elasticities are taken from the existing literature. These parameters are presented in Table A1. Endogenous variables are gasoline supply, demand, and price: ethanol supply, demand, and price; corn price and production; corn use for ethanol, domestic use, and exports; DDGS supply and price; land used for corn; and the price of the composite input for corn. Exogenous variables include crude oil price, corn yield, ethanol conversion rate, ethanol subsidy level and policy mechanism, and gasoline demand shock (due to non-price variables such as population and income). For previous analyses, a 5\% demand shock had been assumed, but it is dropped for this analysis as explained in the text. The model is driven and solved by market clearing conditions that corn supply equal the sum of corn demands and that ethanol production expands to the point of zero profit. 
Table A1. Major model parameters

Parameter

Value

Own price elasticity of demand for corn for domestic use ${ }^{1} \quad-0.1$

Own price elasticity for corn for exports ${ }^{1} \quad-0.5$

Own price elasticity for corn supply ${ }^{2}$

0.4

Own price elasticity for gasoline demand ${ }^{3}$

0.08

Own price elasticity for gasoline supply ${ }^{4}$

Own price elasticity for ethanol supply

0.4

DDGS price $(\$ /$ ton $)=70.12+12.57$ * Price of corn $(\$ / b u)^{6}$

Corn variable costs $(\$ / \mathrm{bu})=0.64+0.0123^{*}$ oil price $(\$ / \mathrm{bbl})^{7}$

1. In this study we assign -0.1 to the domestic demand elasticity (a bit lower than normal) because we assume that DDGS is a perfect substitute for corn and it covers a portion of the domestic demand for corn. We assigned -0.5 to the elasticity of foreign demand for corn according to the Database for Trade Liberalization Studies (Sullivan et al. 1989).

2. This parameter is based on Westcott (1998) and White and Shideed (1991).

3. This parameter is taken from Hughes, Knittel, and Sperling (2006).

4. This parameter is taken from Parry and Small (2003).

5. Several papers has reported or used very inelastic supply functions for ethanol (examples are Miranowski (2007) and Rask (1998)). We also assigned a small value to the short run price elasticity of ethanol supply.

6. This equation is taken from Tyner and Taheripour (2007).

7. This equation if obtained from a time series for the period of 1975-2006. For the work on this paper, the equation was changed to corn $=0.64+$ $.00615{ }^{*}$ crude. 


\section{References}

@Risk, 2008. Risk Analysis and Simulation Add-In for Microsoft Excel. Palisade Corporation

Dale, R.T., Tyner, W.E., 2006a. Economic and Technical Analysis of Ethanol Dry-Milling: Model Description., Staff paper series. Purdue University, West Lafayette, IN.

Dale, R.T., Tyner, W.E., 2006b. Economic and Technical Analysis of Ethanol Dry-Milling: Model Users Manual Staff Paper series. Purdue University, West Lafayette, IN.

Perkis, D., Tyner, W.E., Dale, R., 2008. Economic Analysis of a Modified Dry Grind Ethanol Process with Recycle of Pretreated and Enzymatically Hydrolyzed Distillers' Grains. Bioresource Technology 99, 5243-5249.

Quear, J., Tyner, W.E., 2006. Development of A Variable Ethanol Subsidy and Comparison with the Fixed Subsidy, Staff Paper series. Purdue University, West Lafayette, IN.

Taheripour, F., Tyner, W.E., 2007. Ethanol Subsidies: Who Gets the Benefits, in: Outlaw, J., Duffield, J., Ernstes (Eds.), Biofuels, Food, and Feed Tradeoffs. Farm Foundation/USDA, St. Louis, Missouri, pp. 91 - 98.

Taheripour, F., Tyner, W.E., 2008. Ethanol Policy Analysis - What Have We Learned So Far? Choices 23, 6-11.

Tyner, W., Taheripour, F., 2008a. Biofuels, Policy Options, and Their Implications: Analyses Using Partial and General Equilibrium Approaches. Journal of Agricultural \& Food Industrial Organization 6, Article 9.

Tyner, W.E., 2007a. Biofuels, Energy Security, and Global Warming Policy Interactions, in: Eagleshan, A., Hardy, R.W.F. (Eds.), National Agricultural Biotechnology Council Agricultural Biofuels: Technology, Sustainability and Profitability (NABC Report 19), South Dakota State University, Brookings, SD. Tyner, W.E., 2007b. Policy Alternatives for the Future Biofuels Industry. Journal of Agricultural and Food Industrial Organization 5, article 2.

Tyner, W.E., 2008a. The US Ethanol and Biofuels Boom: Its Origins, Current Status, and Future Prospects. BioScience 58, 646-653.

Tyner, W.E., 2008b. The US Ethanol and Biofuels Boom: Its Origins, Current Status, and Future Prospects. BioScience 58, 646-653.

Tyner, W.E., Dooley, F., Hurt, C., Quear, J., 2008. Ethanol Pricing Issues for 2008. Industrial Fuels and Power, 50-57.

Tyner, W.E., Quear, J., 2006. Comparison of A Fixed and Variable Corn Ethanol Subsidy. Choices 21, 199-202.

Tyner, W.E., Taheripour, F., 2008b. Impacts of an Ethanol Blending Wall on Corn Price and Ethanol Production, in: Purdue University (Ed.), Department of Agricultural Economics.

Tyner, W.E., Taheripour, F., 2008c. Policy Analysis for Integrated Energy and Agricultural Markets in a Partial Equilibrium Framework, Transition to a BioEconomy Conference. Integration of Agricultural and Energy Systems Atlanta, GA, pp. 1-15. 
Tyner, W.E., Taheripour, F., 2008d. Policy Options for Integrated Energy and Agricultural Markets. Review of Agricultural Economics 30, 387-396.

U.S. Congress, 2007. Energy Independence and Security Act of 2007, H.R. 6, 110 Congress, 1 st session. 
Table 1. Illustration of the Variable Subsidy Starting at $\$ 80$ and Changing at 0.50 cents/l./\$

\begin{tabular}{cc}
\hline Crude Oil Price/bbl & Subsidy (Cent/l.) \\
\hline$\$ 80$ or greater & 0 \\
$\$ 70$ & 5 \\
$\$ 60$ & 10 \\
$\$ 50$ & 15 \\
$\$ 40$ & 20 \\
\hline
\end{tabular}


Table 2. Simulation Results for a Range of Subsidy Start Points and Rates of Change

\begin{tabular}{|c|c|c|c|c|c|c|c|}
\hline Crude oil price $\$ / \mathbf{b b l}$ & 40 & 60 & 80 & 100 & 120 & 140 & 160 \\
\hline \multicolumn{8}{|l|}{ Ethanol production (Bil.I./yr.) } \\
\hline $\begin{array}{l}\text { Fixed subsidy (6.6 cents/l.) } \\
\text { Variable: } 0.40 \text { cents } \$ 1 \text { below }\end{array}$ & 0.0 & 25.1 & 47.6 & 62.3 & 72.7 & 80.5 & 86.5 \\
\hline $\begin{array}{l}\$ 90 / l . \\
\text { Variable: } 0.46 \text { cents } / \$ 1 \text { below }\end{array}$ & 36.7 & 40.4 & 41.4 & 49.3 & 61.6 & 70.7 & 77.8 \\
\hline $\begin{array}{l}\$ 90 / . \text {. } \\
\text { Variable: } 0.53 \text { cents } / \$ 1 \text { below }\end{array}$ & 47.8 & 45.9 & 43.0 & 49.3 & 61.6 & 70.7 & 77.8 \\
\hline$\$ 90 / 1$. & 58.3 & 51.2 & 44.5 & 49.3 & 61.6 & 70.7 & 77.8 \\
\hline \multicolumn{8}{|l|}{ Ethanol production (Bil.I./yr.) } \\
\hline $\begin{array}{l}\text { Fixed subsidy ( } 6.6 \text { cents/l.) } \\
\text { Variable: } 0.40 \text { cents } \$ 1 \text { below }\end{array}$ & 0.0 & 25.1 & 47.6 & 62.3 & 72.7 & 80.5 & 86.5 \\
\hline $\begin{array}{l}\$ 80 / \mathrm{l} \text {. } \\
\text { Variable: } 0.46 \text { cents } \$ 1 \text { below }\end{array}$ & 22.5 & 29.0 & 31.8 & 49.3 & 61.6 & 70.7 & 77.8 \\
\hline $\begin{array}{l}\$ 80 / l . \\
\text { Variable: } 0.53 \text { cents } / \$ 1 \text { below }\end{array}$ & 32.0 & 32.9 & 31.8 & 49.3 & 61.6 & 70.7 & 77.8 \\
\hline$\$ 80 /$. & 41.2 & 36.7 & 31.8 & 49.3 & 61.6 & 70.7 & 77.8 \\
\hline \multicolumn{8}{|l|}{ Ethanol production (Bil.I./yr.) } \\
\hline $\begin{array}{l}\text { Fixed subsidy ( } 6.6 \text { cents/l.) } \\
\text { Variable: } 0.40 \text { cents } \$ 1 \text { below }\end{array}$ & 0.0 & 25.1 & 47.6 & 62.3 & 72.7 & 80.5 & 86.5 \\
\hline $\begin{array}{l}\$ 70 / . \\
\text { Variable: } 0.46 \text { cents } / \$ 1 \text { below }\end{array}$ & 7.2 & 17.1 & 31.8 & 49.3 & 61.6 & 70.7 & 77.8 \\
\hline $\begin{array}{l}\$ 70 / l . \\
\text { Variable: } 0.53 \text { cents } \$ 1 \text { below }\end{array}$ & 15.0 & 19.1 & 31.8 & 49.3 & 61.6 & 70.7 & 77.8 \\
\hline$\$ 70 / 1$. & 22.5 & 21.1 & 31.8 & 49.3 & 61.6 & 70.7 & 77.8 \\
\hline \multicolumn{8}{|l|}{ Corn price $(\$ / m t)$} \\
\hline ts $/$. .) & 67.6 & 94.1 & $\begin{array}{r}126 . \\
6\end{array}$ & $\begin{array}{r}156 . \\
9\end{array}$ & $\begin{array}{r}185 . \\
6\end{array}$ & $\begin{array}{r}213 . \\
0\end{array}$ & $\begin{array}{r}239 . \\
4\end{array}$ \\
\hline 0.40 cents $/ \$ 1$ below & & 108. & 119. & 138. & 167. & 194. & 220. \\
\hline & 96.1 & 9 & 3 & 6 & 0 & 3 & 7 \\
\hline Variable: 0.46 cents $/ \$ 1$ below & 106. & 114. & 121. & 138. & 167. & 194. & 220. \\
\hline & & 7 & 1 & 6 & 0 & 3 & \\
\hline $\begin{array}{l}\text { Variable: } 0.53 \text { cents } / \$ 1 \text { below } \\
\$ 90 / l .\end{array}$ & $\begin{array}{r}117 . \\
2\end{array}$ & $\begin{array}{r}120 . \\
6\end{array}$ & $\begin{aligned} & 122 . \\
& 9\end{aligned}$ & $\begin{array}{r}138 . \\
6\end{array}$ & $\begin{aligned} 167 . \\
0\end{aligned}$ & $\begin{array}{r}194 . \\
3\end{array}$ & $\begin{aligned} 220 . \\
7\end{aligned}$ \\
\hline \multicolumn{8}{|l|}{ Corn price $(\$ / \mathrm{mt})$} \\
\hline $\begin{array}{l}\text { Fixed subsidy ( } 6.6 \text { cents/l.) } \\
\text { Variable: } 0.40 \text { cents } \$ 1 \text { below }\end{array}$ & 67.6 & 94.1 & $\begin{array}{r}126 . \\
6 \\
108 .\end{array}$ & $\begin{array}{r}156 . \\
9 \\
138 .\end{array}$ & $\begin{array}{r}185 . \\
6 \\
167 .\end{array}$ & $\begin{array}{r}213 . \\
0 \\
194 .\end{array}$ & $\begin{array}{r}239 . \\
4 \\
220 .\end{array}$ \\
\hline & 84.0 & 97.7 & 6 & 6 & 0 & & 7 \\
\hline Variable: 0.46 cents $/ \$ 1$ below & & 101. & 108. & 138. & 167. & 194. & 220. \\
\hline$\$ 80 /$. & 2.0 & 4 & 6 & 6 & 0 & 3 & 7 \\
\hline Variable: 0.53 cents $/ \$ 1$ below & 100. & 105. & 108. & 138. & 167. & 194. & 220. \\
\hline$\$ 80 / 1$. & 0 & 1 & 6 & 6 & 0 & 3 & 7 \\
\hline \multicolumn{8}{|l|}{ Corn price $(\$ / \mathrm{mt})$} \\
\hline Fixed subsidy (6.6 cents/l.) & 67.6 & 94.1 & 126. & 156. & 185. & 213. & 239. \\
\hline
\end{tabular}




\begin{tabular}{|c|c|c|c|c|c|c|c|}
\hline & & & 6 & 9 & 6 & 0 & 4 \\
\hline Variable: 0.40 cents $/ \$ 1$ below & & & 108. & 138. & 167. & 194. & 220. \\
\hline$\$ 70 / l$. & 72.6 & 87.0 & 6 & 6 & 0 & 3 & 7 \\
\hline Variable: 0.46 cents $/ \$ 1$ below & & & 108. & 138. & 167. & 194. & 220. \\
\hline$\$ 70 / \mathrm{l}$. & 78.2 & 88.7 & 6 & 6 & 0 & 3 & 7 \\
\hline Variable: 0.53 cents $/ \$ 1$ below & 100. & 105. & 108. & 138. & 167. & 194. & 220. \\
\hline$\$ 70 / l$. & 2 & 1 & 6 & 6 & 0 & 3 & 7 \\
\hline
\end{tabular}


Table 3. Results for the Fixed Trigger Price Nominal Variable Subsidy Case

\begin{tabular}{|c|c|c|c|c|c|c|c|c|c|}
\hline \multirow{3}{*}{$\begin{array}{l}\text { Volume Priced } \\
\text { Ethanol } \\
\text { NPV, Financial w/tax }\end{array}$} & \multicolumn{9}{|c|}{ Annual Outlook Projected Crude Starting Price } \\
\hline & \multicolumn{4}{|c|}{ Firm NPV } & \multicolumn{3}{|c|}{ Subsidy NPV } & \multicolumn{2}{|c|}{$\begin{array}{l}\text { Govt NPV } \\
\text { revenue }\end{array}$} \\
\hline & Value & Mean & SD & SD/Mean & $\%<0$ & Mean & SD & Mean & SD \\
\hline Fixed Subsidy & 355 & 343 & 326 & 0.95 & 6.6 & 316 & 0 & -145 & 109 \\
\hline $\begin{array}{l}\text { Var. Subsidy } \\
(110,0.0046)\end{array}$ & 267 & 381 & 222 & 0.58 & 0.0 & 376 & 248 & -183 & 256 \\
\hline $\begin{array}{l}\text { Var. Subsidy }(100,0 . \\
0046)\end{array}$ & 216 & 326 & 239 & 0.73 & 0.0 & 289 & 217 & -128 & 234 \\
\hline $\begin{array}{l}\text { Var. Subsidy }(90,0 . \\
0046)\end{array}$ & 178 & 281 & 252 & 0.90 & 0.3 & 213 & 183 & -79 & 212 \\
\hline $\begin{array}{l}\text { Var. Subsidy }(80,0 . \\
0046)\end{array}$ & 162 & 240 & 269 & 1.12 & 3.8 & 147 & 147 & -36 & 188 \\
\hline $\begin{array}{l}\text { Var. Subsidy }(70,0 . \\
0046)\end{array}$ & 162 & 209 & 288 & 1.38 & 17.3 & 95 & 113 & -2 & 167 \\
\hline No Subsidy & 162 & 149 & 326 & 2.19 & 39.4 & 0 & 0 & 58 & 109 \\
\hline $\begin{array}{l}\text { Volume Priced } \\
\text { Ethanol }\end{array}$ & \multicolumn{9}{|c|}{ Current Market Crude Starting Price } \\
\hline \multirow[t]{2}{*}{ NPV, Financial w/tax } & \multicolumn{5}{|c|}{ Firm NPV } & \multicolumn{2}{|c|}{ Subsidy NPV } & \multicolumn{2}{|c|}{$\begin{array}{c}\text { Govt NPV } \\
\text { revenue }\end{array}$} \\
\hline & Value & Mean & SD & SD/Mean & $\%<0$ & Mean & SD & Mean & SD \\
\hline Fixed Subsidy & 245 & 242 & 269 & 1.11 & 12.3 & 316 & 0 & -179 & 89 \\
\hline $\begin{array}{l}\text { Var. Subsidy }(110,0 . \\
0046)\end{array}$ & & & & & & & & & \\
\hline $\begin{array}{l}\text { Var. Subsidy }(100,0 . \\
0046)\end{array}$ & 191 & 282 & 178 & 0.63 & 0.0 & 383 & 215 & -223 & 216 \\
\hline $\begin{array}{l}\text { Var. Subsidy }(90,0 . \\
0046)\end{array}$ & 132 & 225 & 190 & 0.84 & 0.3 & 290 & 187 & -162 & 198 \\
\hline $\begin{array}{l}\text { Var. Subsidy }(80,0 . \\
0046)\end{array}$ & 84 & 176 & 209 & 1.19 & 4.8 & 206 & 158 & -108 & 180 \\
\hline $\begin{array}{l}\text { Var. Subsidy }(70,0 . \\
0046)\end{array}$ & 55 & 129 & 223 & 1.73 & 26.1 & 131 & 124 & -60 & 155 \\
\hline
\end{tabular}




\begin{tabular}{lllllllll}
\hline No Subsidy & 52 & 50 & 270 & 5.40 & 54.5 & 0 & 0 & 25 \\
\hline
\end{tabular}


Table 4. Results for the Inflation Adjusted Trigger Price Variable Subsidy Case

\begin{tabular}{|c|c|c|c|c|c|c|c|c|c|}
\hline \multirow{3}{*}{$\begin{array}{l}\text { Volume Priced } \\
\text { Ethanol } \\
\text { NPV, Financial w/tax }\end{array}$} & \multicolumn{9}{|c|}{ Annual Outlook Projected Crude Starting Price } \\
\hline & \multicolumn{5}{|c|}{ Firm NPV } & \multicolumn{2}{|c|}{ Subsidy NPV } & \multicolumn{2}{|c|}{$\begin{array}{l}\text { Govt NPV } \\
\text { revenue }\end{array}$} \\
\hline & Value & Mean & SD & SD/Mean & $\%<0$ & Mean & SD & Mean & SD \\
\hline Fixed Subsidy & 355 & 343 & 326 & 0.95 & 6.6 & 316 & 0 & -145 & 109 \\
\hline $\begin{array}{l}\text { Var. Subsidy }(80,0 . \\
0046)\end{array}$ & 228 & 373 & 216 & 0.58 & 0.0 & 363 & 261 & -176 & 266 \\
\hline $\begin{array}{l}\text { Var. Subsidy }(70,0 . \\
0046)\end{array}$ & 162 & 309 & 241 & 0.78 & 0.1 & 257 & 213 & -107 & 234 \\
\hline $\begin{array}{l}\text { Var. Subsidy }(60,0 . \\
0046)\end{array}$ & 162 & 258 & 268 & 1.04 & 1.7 & 172 & 165 & -51 & 202 \\
\hline $\begin{array}{l}\text { Var. Subsidy }(50,0 . \\
0046)\end{array}$ & 162 & 218 & 290 & 1.33 & 14.6 & 108 & 118 & -10 & 172 \\
\hline No Subsidy & 162 & 149 & 326 & 2.19 & 39.4 & 0 & 0 & 58 & 109 \\
\hline $\begin{array}{l}\text { Volume Priced } \\
\text { Ethanol }\end{array}$ & \multicolumn{9}{|c|}{ Current Market Crude Starting Price } \\
\hline NPV, Financial w/tax & \multicolumn{5}{|c|}{ Firm NPV } & \multicolumn{2}{|c|}{ Subsidy NPV } & \multicolumn{2}{|c|}{$\begin{array}{l}\text { Govt NPV } \\
\text { revenue }\end{array}$} \\
\hline & Value & Mean & SD & SD/Mean & $\%<0$ & Mean & SD & Mean & SD \\
\hline Fixed Subsidy & 245 & 242 & 269 & 1.11 & 12.3 & 316 & 0 & -179 & 89 \\
\hline $\begin{array}{l}\text { Var. Subsidy }(70,0 . \\
0046)\end{array}$ & 144 & 252 & 180 & 0.71 & 0.0 & 330 & 221 & -188 & 222 \\
\hline $\begin{array}{l}\text { Var. Subsidy }(60,0 . \\
0046)\end{array}$ & 52 & 181 & 195 & 1.08 & 2.6 & 217 & 175 & -116 & 190 \\
\hline $\begin{array}{l}\text { Var. Subsidy }(50,0 . \\
0046)\end{array}$ & 52 & 132 & 221 & 1.67 & 23.4 & 136 & 129 & -63 & 161 \\
\hline No Subsidy & 52 & 50 & 270 & 5.40 & 54.5 & 0 & 0 & 25 & 90 \\
\hline
\end{tabular}


Figure 1. Renewable Fuel Standard

Figure 2. Ethanol Subsidies and Non-Binding RFS

Figure 3. Ethanol Subsidies and Binding RFS

Figure 4. Impact of Tariff removal with Binding RFS and Low Cost Imported Ethanol

Figure 5. Base Comparison of Ethanol Production under Subsidy Options and RFS

Figure 6. Base Comparison of Corn Price under Subsidy Options and RFS

Figure 7. Corn Exports Under Alternative Policy Options

Figure 8. Ethanol Production under Different Fixed and Variable Subsidy Options

Figure 9. Corn Price under Different Fixed and Variable Subsidy Options

Figure 10. Win-win Cases for Nominal Oil Trigger Price

Figure 11. Win-win Cases for the Real Oil Trigger Price 


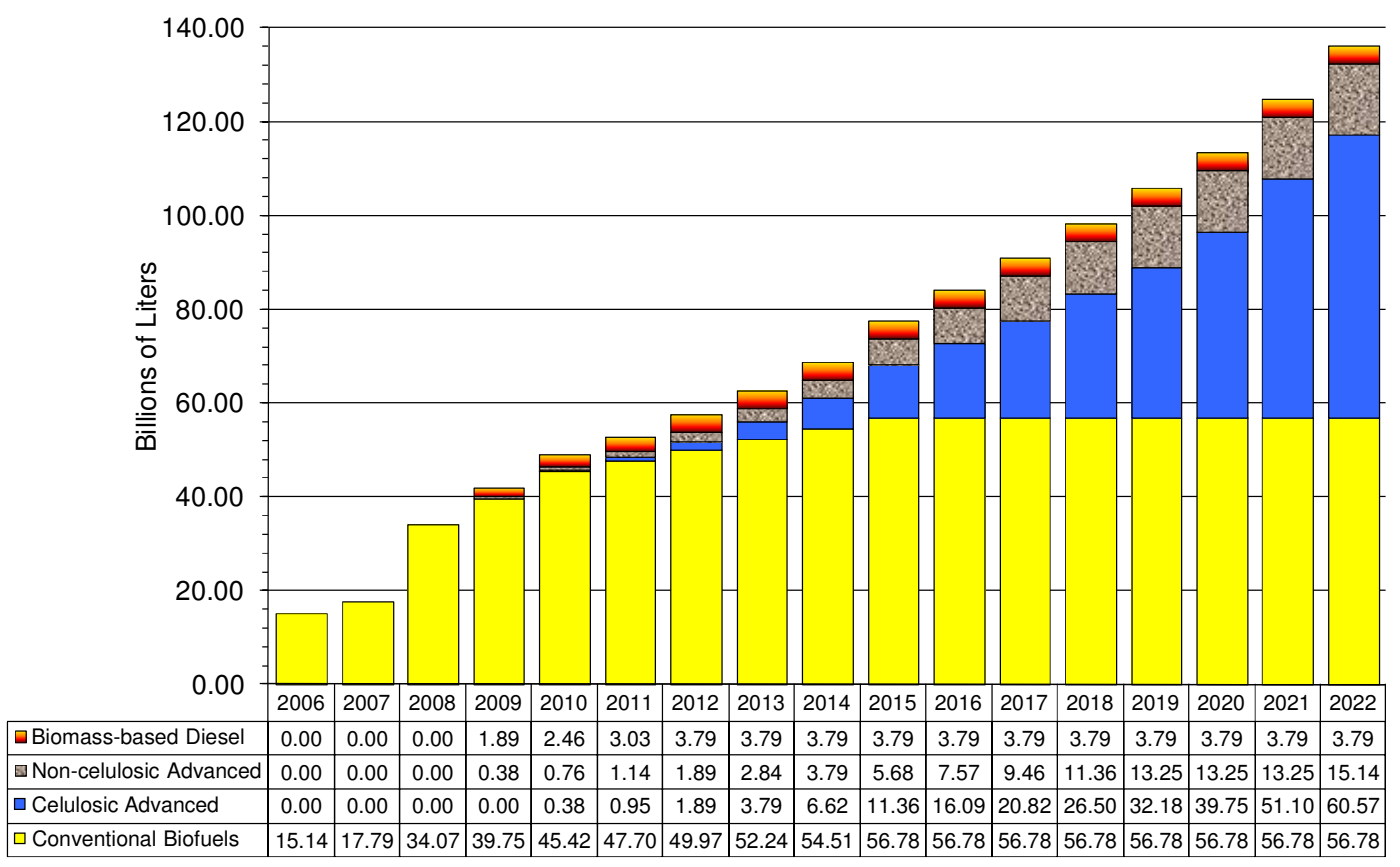




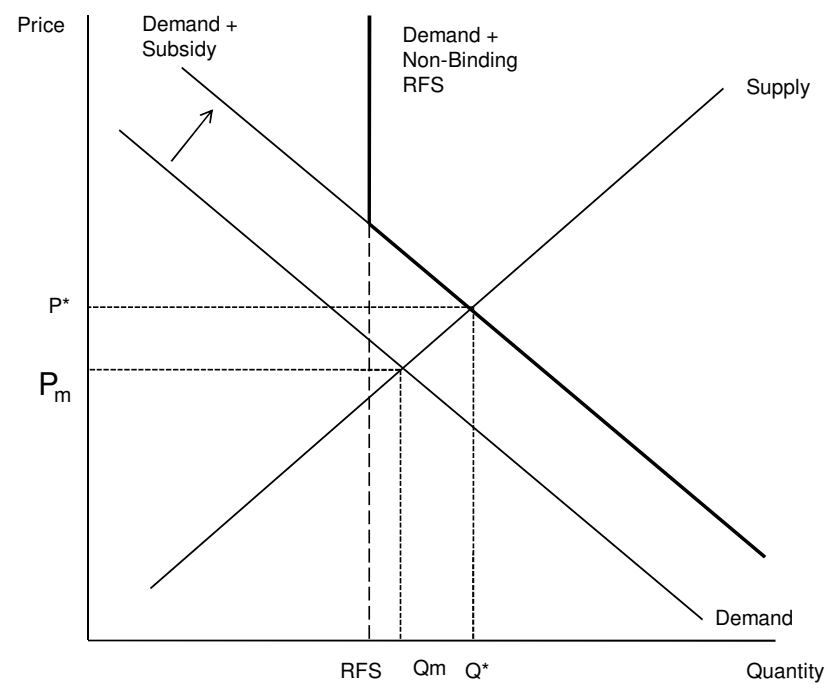




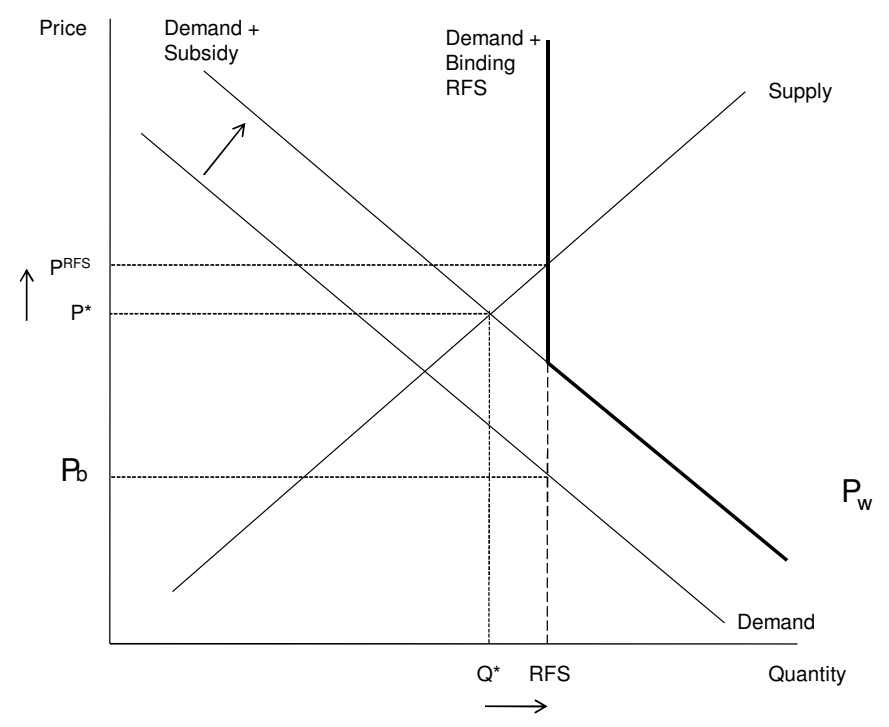




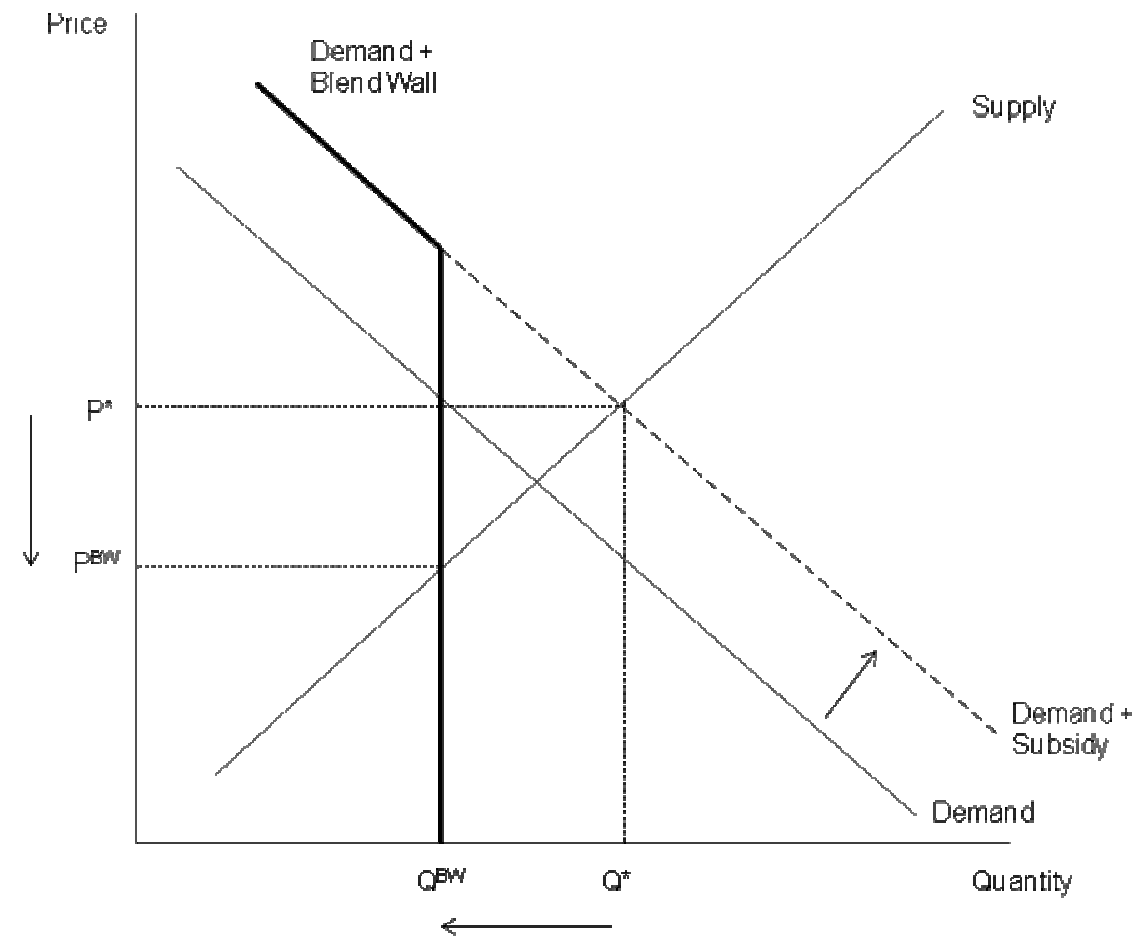




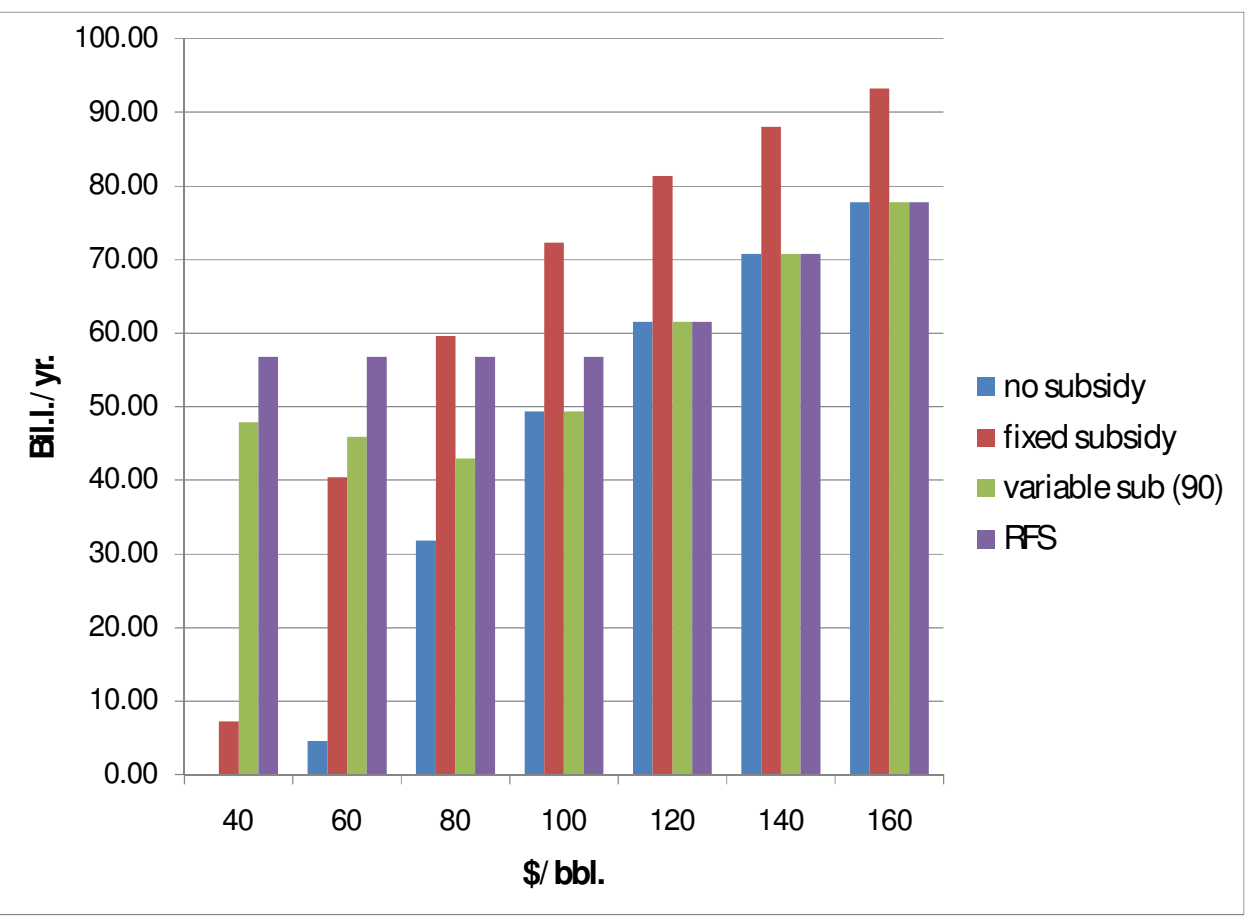


39

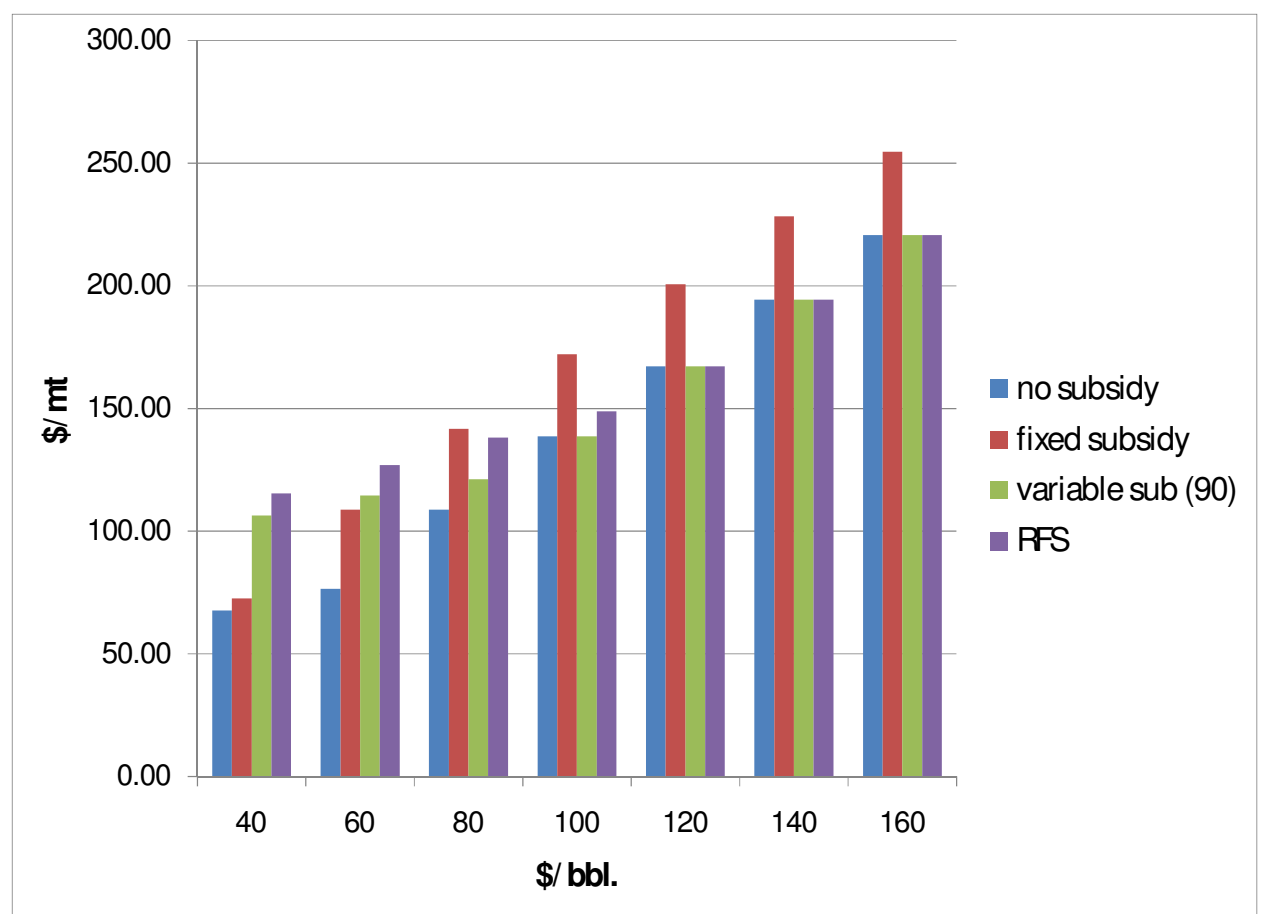

6 


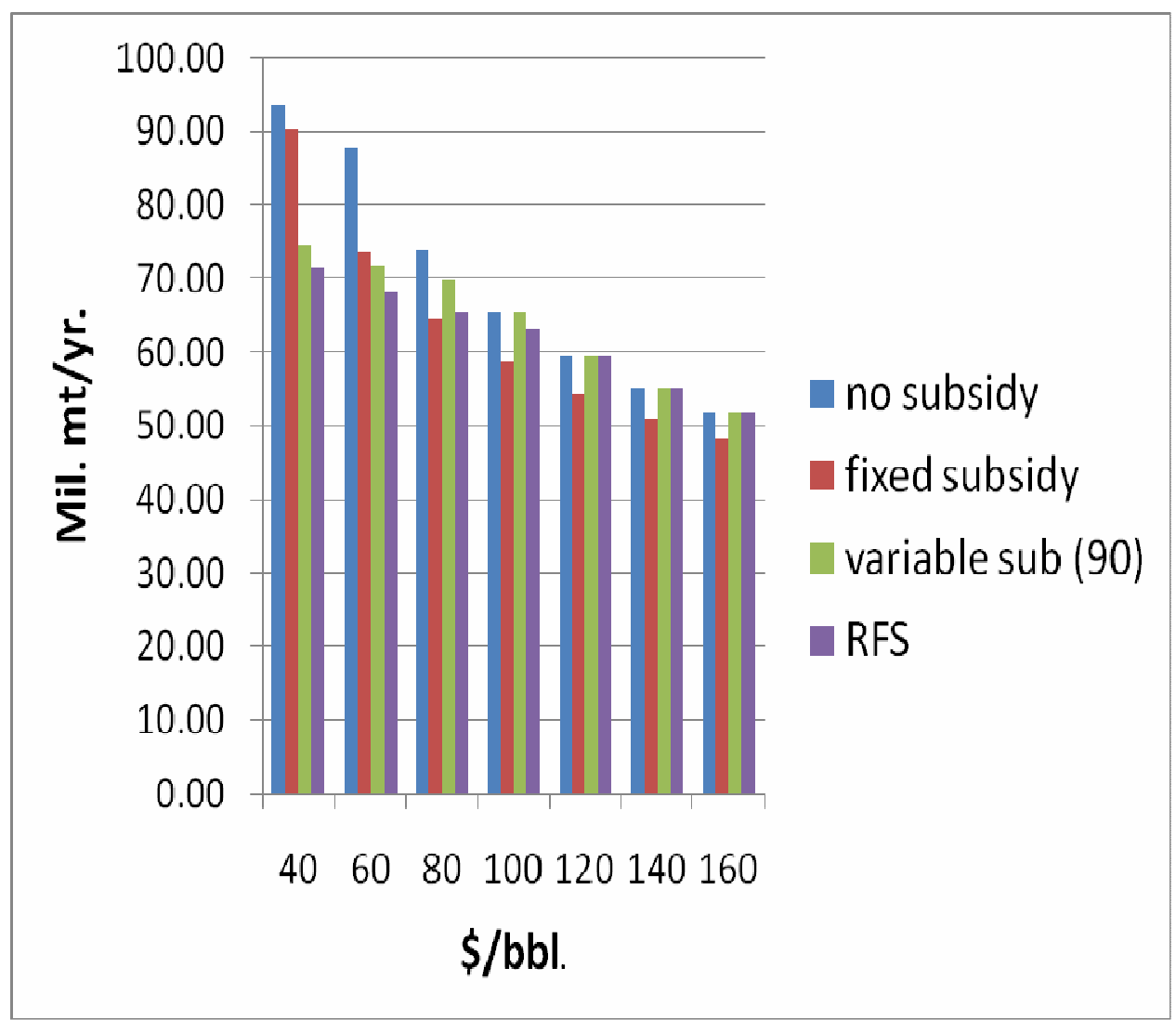

7 


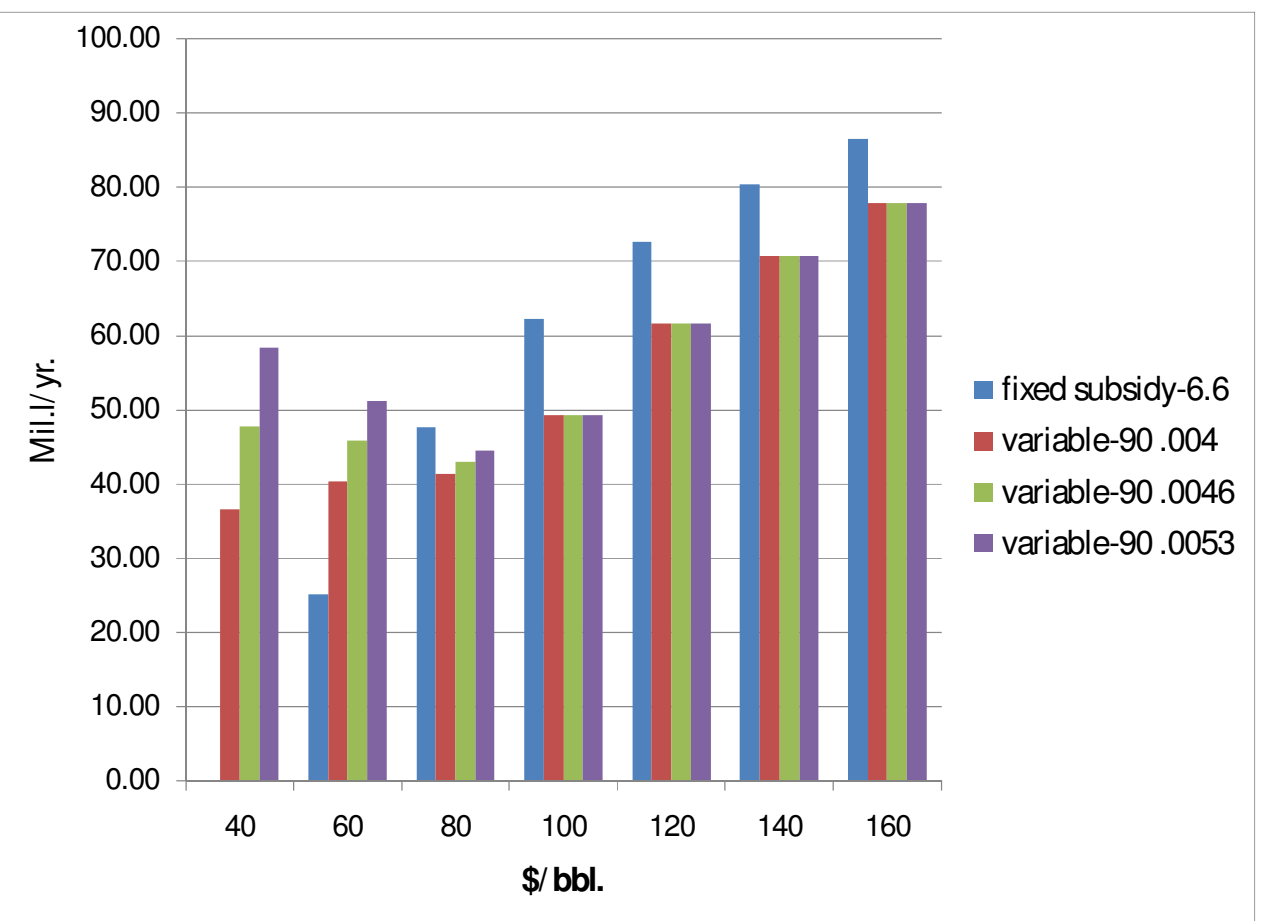

8 


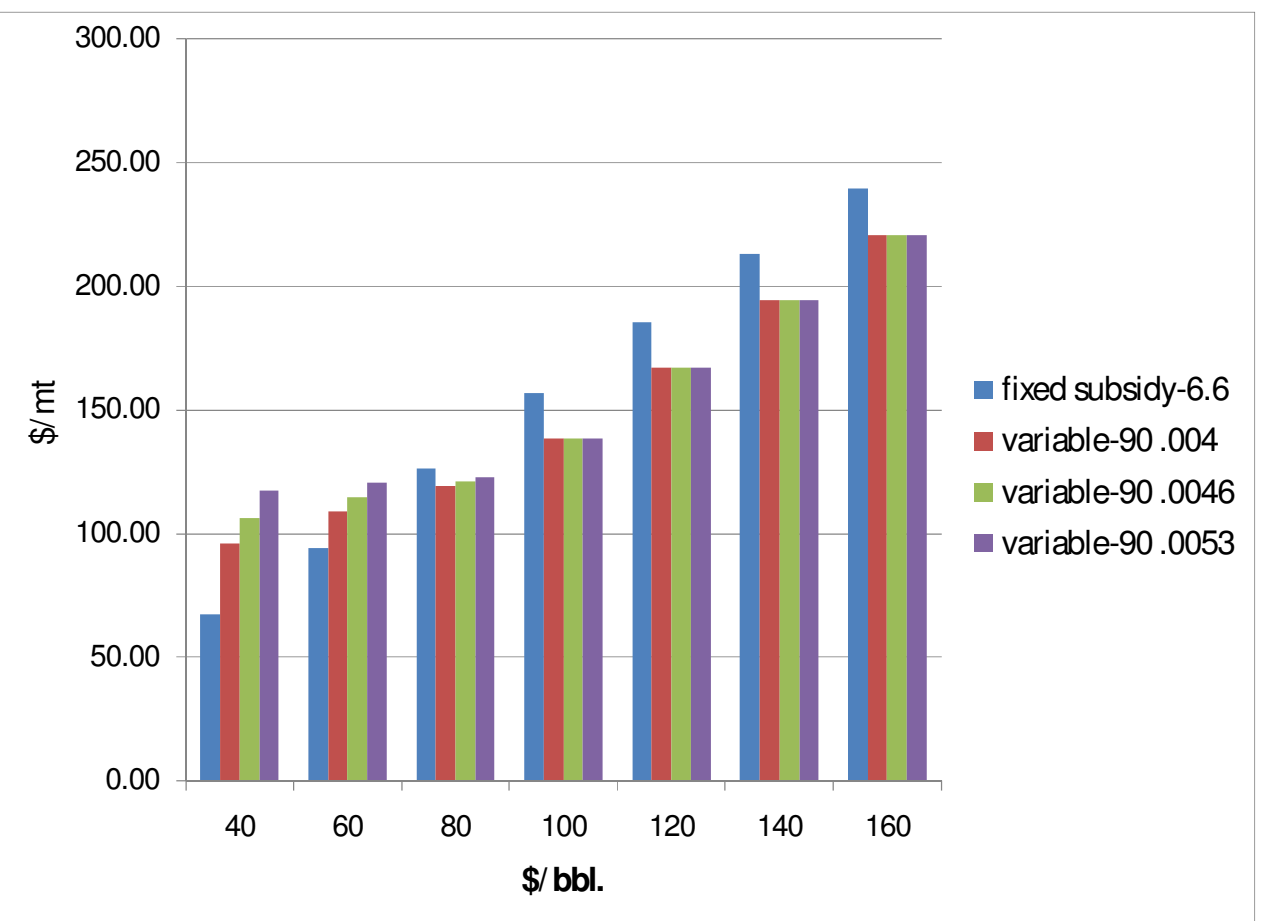

9 


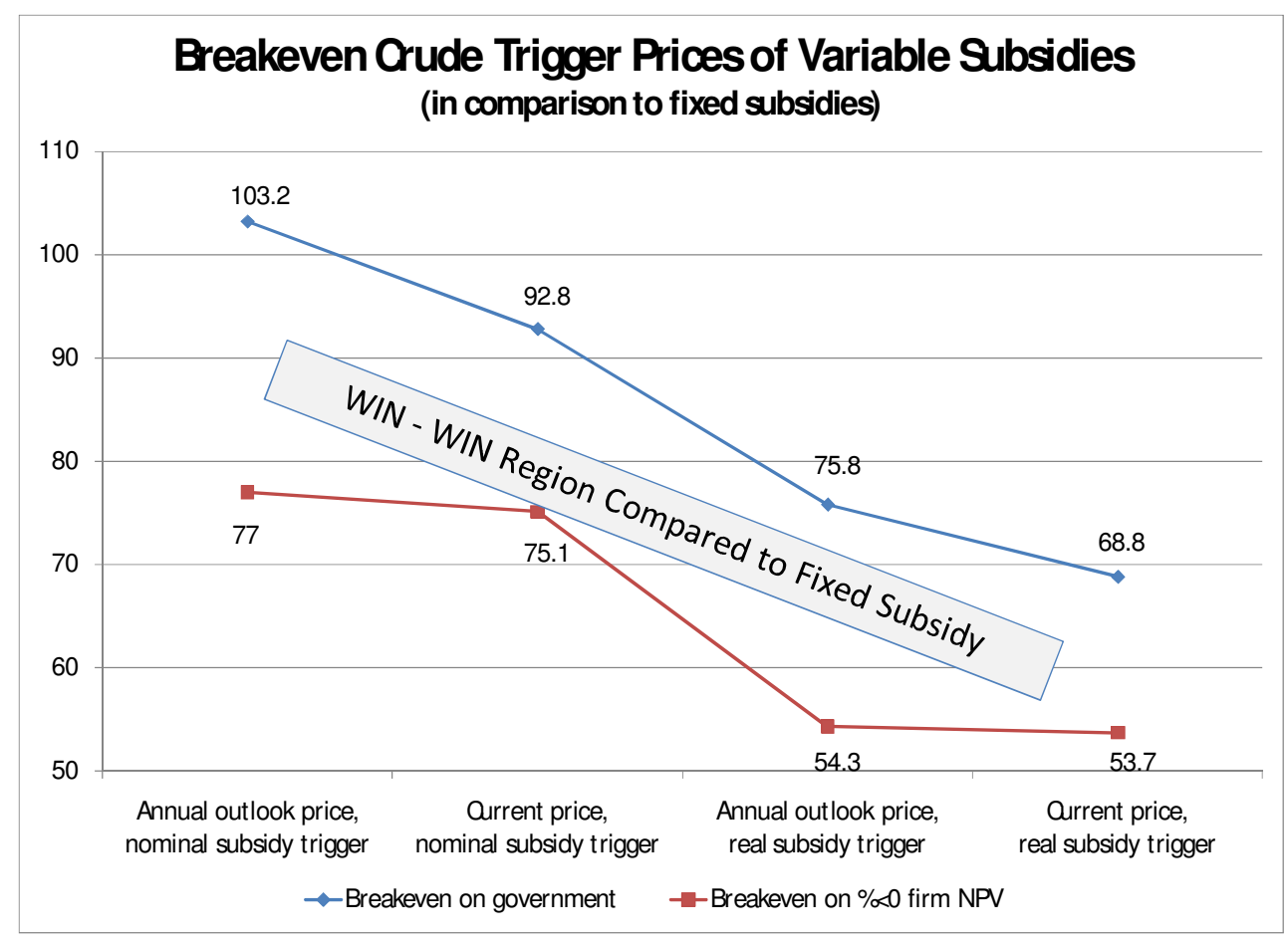

10 